JOURNAL OF SECURITY AND SUSTAINABILITY ISSUES

ISSN 2029-7017 print/ISSN 2029-7025 online

2019 June Volume 8 Number 4

https://doi.org/10.9770/jssi.2019.8.4(2)

Scopus

\title{
EVALUATIONS OF SECURITY MEASURES AND IMPACT OF GLOBALIZATION ON CHARACTERISTICS OF PARTICULAR PROPERTY CRIMES
}

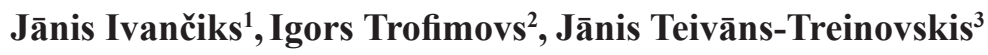 \\ ${ }^{1,3}$ Turiba University, Graudu Str. 68, Riga, LV-1058, Latvia \\ ${ }^{2}$ The State Police College of Latvia, Ezermalas Str. 8, Riga, LV-1014, Latvia \\ ${ }^{3}$ Dangavpils University, Parades Str. 1, Daugavpils, LV-5401, Latvia \\ E-mails: ${ }^{2}$ dakpt@inbox.lv, ${ }^{3}$ janisteivans@inbox.lv
}

Received 10 October 2018; accepted 25 December 2018; published March 302019

\begin{abstract}
In the epoch when terrorism and other serious crimes are cross-border problem, both the European Union and its Member States are responsible to their citizens for full ensuring of area of their internal security. Criminal offences against property or property crimes endanger the property of individuals and legal entities, as well as jeopardize their property interests. Consequently, the property rights, which are jeopardized by the crimes, are guaranteed by the State and are ensured by the Law Enforcement Authorities. Quantitatively, the largest group of criminal offences is composed by the crimes that can only be done on purpose of greediness, and most of them express themselves as the unlawful expropriation of the unfamiliar property from the lawful possession, in order to deal with that asset as their own. Such crimes are theft, robbery, extortion, fraud, and they together form more than half of all offences committed. For their research, the authors of the article have chosen the crimes with high public hazard degree from the offences against property. These offences are most of all affected by the globalization processes in the world, and they are: crimes related to a transport vehicle as a threat object; thefts from cultural objects where the objects of danger are churches or religious articles; modern frauds, when during their realization modern technical tools and new technologies are used. During the research, the co-author of the article - Prof. Dr. Jānis Ivančiks, has deceased suddenly. However, the years of joint work, discussions and scientific disputes, that accompanied the writing of this article and other written works allow co-authors to maintain the position and scientific views of this outstanding scientist in the field of forensic investigations and operational activities of special divisions. The authors show in this work the creative activity in the field of legal norms which affect personal property of individuals and their feeling, when the lawmakers eliminate the unnecessary rules, create new or improve existing ones in accordance with the country's political, economic situation and globalization processes.
\end{abstract}

Keywords: globalization; crimes; security measures; criminal offences; psychological methods; truthful evidence.

Reference to this paper should be made as follows: Ivančiks, J.; Trofimovs, I.; Teivāns-Treinovskis, J. 2019. Evaluations of security measures and impact of globalization on characteristics of particular property crimes, Journal of Security and Sustainability Issues, 8(4): 569-579. https://doi.org/10.9770/jssi.2019.8.4(2)

JEL Classifications: K42, O10, P00

Additional disciplines: law, criminal law

\section{Introduction}

Nowadays more and more attention is paid to the problems of the security of the society and ensure of public order, since security and public order is seen as precondition of sustainable development (Čentéš et al. 2018; Dworzecki, Nowicka 2019; Laužikas, Miliūtė 2019). This joint publication will appeal some issues in secure development in the area of particular property crimes. Similar issues were previously examined by such scientists as Tumalavičius, V.; Zahars, V., Stivrinieks, M., Teivans-Treinovskis, J., Šakočius, A., Greičius, S., Trofimovs, I. and etc. (Tumalavičius et al. 2017; Tumalavičius, Veikša et al. 2017; Tumalavičius, Greičius 2017; Tumalavičius, Šakočius 2017; Zahars, Stivrenieks 2016; Nesterova, Teivans-Treinovskis, Ivančiks 2015; 
Ivančiks, Tumalavičius, Teivans-Treinovskis 2015; Trofimovs, Ivančiks 2017).

On the territory of Latvia, theft was punishable among Ancient Latvian tribes since ancient times, including after the adoption of Christianity (Shteyman 2005, p. 9) in the 13th Century - during Livonia time, then during dependence time in the Polish-Lithuanian Commonwealth according to the Lübeck Law and the Magdeburg Rights (Brežgo 2009, p. 31). It was also punished based on the Statutes of the Grand Duchy of Lithuania (Shteyman 2005, p. 27), as well as during so called Swedish Times. After the Treaty of Nystad of 1721 between the Tsardom of Russia and the Swedish Empire, the northern part of the territory of modern Latvia came into the Russian Empire, and offenders who committed crimes in this territory were punished in accordance with the Sudebnik (Code of Laws) of 1497 (Samokvasov D.YA ., 1908, 408). On 1 May 1846, in the Baltic Provinces of the Russian Empire, the Russian Criminal and Correctional Code (Regulations on Criminal and Correctional Punishments - Ulozhenie o nakazaniyakh ugolovnykh i ispravitelnykh 1846) came into force. However, with the rapid development of the economy and social rights, a completely new necessity of criminal law arose, and, on 22 March 1903, Emperor of Russia Nikolas II approved the new Criminal Code (hereinafter - the Russian Criminal Code).

The Russian Criminal Code was effective and existed throughout the territory of Latvia until the Independence of Latvia, even during the German occupational power until the end of 1918. When Latvia was proclaimed independent on 18 November 1918, in accordance with the Law of 6 December 1918, the Criminal Code of 1903 was also introduced in Latvia. It was the first edition of the Criminal Code in the state language - Latvian, the text of the Law was left unchanged, and only in the explanations, under each separate section of the Law, is specified how far this Law could apply in Latvia, omitting unnecessary and non-compliant norms in the situation of that time.

On 1 August 1933, the new Criminal Code came into effect. The Criminal Code of 1903 was the basis of the new Criminal Code. Moreover, the principles of compliance with new elaborated Codes of Switzerland (1918), Czechoslovakia (1926), Germany (1927) and Italy (1930) were taken into account (The Criminal Code of 1933). The new Criminal Code clarified certain concepts and systematized qualifying conditions; instead of the original 687 basic sections of the old Penal Law, the new Penal Code covers 584 sections.

After the occupation and integration of Latvia into the Union of Soviet Socialist Republics (hereinafter - the USSR), the Criminal Code of the Russian Soviet Federative Socialist Republic (adopted in 1926, hereinafter referred to as the Russian Criminal Code) was introduced on the territory of Latvia for temporary use. This Criminal Code entered into force in Latvia on 26 November 1940. During the Second World War, the Nazi Germany occupation administration restored the operation of the Criminal Code of 1933 on the territory of Latvia. However, after the Nazi German withdrawal, the Russian Criminal Code of 1926, which, with some amendments, was in force until 1961, was again in force.

Since 11 February 1957, the development of a new criminal code began (Ugolovnyy Kodeks Latviyskoy Sovetskoy Sotcialisticheskoy Respubliki, 1983, Art. 247). The Criminal Code of the Latvian Soviet Socialist Republic (hereinafter - the Latvian SSR) entered into force on 1 April 1961.

In accordance with the political and economic situation of the state, since 22 August 1991, the Criminal Code of the Latvian SSR, with significant amendments, was regarded as the Criminal Code of Latvia (hereinafter the CC of Latvia).

On 17 June 1998, the Saeima of the Republic of Latvia adopted the Criminal Law currently in force in Latvia, which came into force on 1 April 1999. The distribution of norms of the Criminal Rights in General and Special Parts within the Criminal Law was not changed; however, changes were made in the layout of the norms. Several norms of the institutions of the Criminal Rights were expanded and elaborated more detailed, as well as the emphasises were placed on the importance of threatened interests. New Chapters were created in the General Part, prescribing the conditions related the criminal liability of minors and the conditions for the 
application of coercive medical treatment. In the Special Part, new Chapters also were created, while the norms in the Chapters were regrouped (Krastiņš 2010, pp. 5-24). In accordance with the international obligations of Latvia, new Chapter was created - crimes against humanity, genocide, crimes against peace, as well as war crimes. Two Chapters of the Special Section of the CC of Latvia - crimes against the state and public property, as well as crimes against personal property of citizens - were united into one Chapter - crimes against property. In order to adjust economic activity in the new economic conditions, a new Chapter was formed - crimes in the national economy. In addition, taking into account international obligations, an important Chapter - criminal offences against the natural environment was created.

For their research, the authors of the article identified from the offenses against property crimes with high public hazard having cross-border aspects: offenses related to a motor vehicle as a threat object; theft from cultural objects where the threat objects are churches or religious items; advanced fraud where during execution modern technical means and new technologies are used. In these crimes, the characteristics of realization completely corresponds to the characteristics of organized criminality, which is defined in the working document of the European Parliament related to the organized criminality. Respectively: organized criminality is definitely a structured group that exists for a long time, consists of more than two persons acting in a coordinated manner, in order to gain, directly or indirectly, financial benefits or other material advantages, exercising intermediary functions, having a significant impact on the economic and social cohesion of the European Union and its Member States and, consequently, on the single market (Working Paper on Organized Crime, 2014, p. 3).

The increased public danger is manifested in the following: significant material damages to victims; great resonance in mass media and in society; the object of danger is of mental value; serial features; specific proportion of recidivists; criminal international contacts; use of modern technologies.

The cross-border dimension is topical because the European Union is established so that it has to ensure the space of freedom (Teivāns-Treinovskis 2017, p. 40), security and justice without its internal borders. Europeans have to feel confidently that everywhere they travel in Europe, their freedom and their security is well protected in accordance with the EU values, including property rights. This cross-border dimension manifests as follows: the identified crimes may start in one country, then continue in other countries and end in another country; stolen items are not distributed in the country where the offence was committed; the crime is committed by nationals of several countries.

Combating and prevention of such crimes requires from law enforcement institutions improvement of their forensics methods and the theory of operational activities (Tumalavičius 2015, p. 357), as well as requires effective cooperation at European level in strengthening our protection and building resistance to these threats.

\section{Criminological and criminal justice characterization of unlawful expropriation of motor vehicles}

All history of the humanity is related to the use of animal assistance in everyday life, whether it is field husbandry or movement of carts, people and goods between different geographic locations, as well as wars. Due to this, since the ancient time, the theft of cattle, horses (Omelchenko 2000, p. 77) together with arson and burglary are among the most serious crimes. The German Law provided stoning or placing onto a pole for horse theft. In the source of rights Russkaya Pravda of Ancient Russia (the Old Russian Law), theft of official/ service horses was considered as the high treason and was punishable by death; for simple theft of a horse, various punishments were foreseen: expulsion of the offender, seizure of property, cutting of the hand, slavery. Regarding a repeated theft of a horse - death penalty (Chistyakov 1984, p. 28-38).

On the territory of Latvia, horse theft was punishable before and after the adoption of Christianity among the Latvian tribes, for example, according to the Statutes of the Grand Duchy of Lithuania - from fines and beating with a whip to hanging (Statut velikogo knyazhestva Litovskogo, 1529, Art.1). After 1721, according to the Sudebnik of 1497, and regarding theft of a horse, the following punishments were prescribed - from beating with a whip or a fine up to the death penalty (Sudebnik, 1497, Art. 8-10). 
Since 1 May 1846, the Russian Regulations on Criminal and Correctional Penalties (Criminal Code 1846) entered into force on the present territory of Latvia, according to which the following responsibility was provided in Article 2166 regarding theft of horses or livestock: ten beatings with a whip up to the deprivation of all rights and death penalty (Ulozhenie o nakazaniyakh ugolovnykh i ispravitel'nykh, 1845, p. 19). On 22 March 1903, Czar Nicholas II approved the Russian Criminal Code, where Article 585 provided responsibility regarding theft of a horse - a sentence from the imprisonment into a house of correction up to forced labour.

After the Russian February Revolution 1917, the Criminal Code were introduced in Latvia where the text of Article 585 of the Russian Criminal Code was retained without any changes. This Criminal Code existed until 1933. On 1 August 1933, the new Criminal Code came into force, where the base of this Code was formed from the Criminal Code of 1903, taking into account the creative work at Laws of Western Europe countries. As a result, former Section 585 of the Criminal Code regarding theft of horses or cattle was excluded from the new Code as such, formulating Article 546 in a generalized manner (Criminal Code, 1933, p. 171).

After the incorporation of Latvia into the USSR, the Russian Criminal Code of 1926 came in force on the territory of Latvia, which, with some amendments, was in force until 1961. Article 166 of the Russian Criminal Code of 1926 prescribed the responsibility for the covert or overt theft of a horse with a deprivation of liberty of up to five years. However, such subjects of crime as a cart, car, motorcycle, bicycle and other vehicles were included in the Chapter 7 "Crimes against property" as a general concept of the property object (Ugolovnyy Kodeks RSFSR redaktsii, 1926, Glava sed'maya Imushchestvennyye prestupleniya).

The Criminal Code of the Latvian SSR contained the Chapter 5 "Crimes against the Personal Property of Citizens", however such threat objects of crime as a horse, motorcycle or car were not separated from the general concept of crime object. Only Article 197 - The unauthorized driving away of a motor vehicle or sailing ships" (in Russian: ugon ) in the Chapter 9 "Crimes against administrative order" - prescribed liability for the unauthorized stealing of cars, motorcycles or other motor vehicles without the purpose of appropriation temporary deprivation of liberty up to one year (Ugolovnyy Kodeks Latviyskoy Sovetskoy Sotsialisticheskaoy Respubliki, 1983, p. 187).

On 6 June 1996, the lawmakers supplemented objects of criminal offence set forth in Article 139, Paragraph 5 with the concepts of car and objects of other motor vehicles, stating Article 139, Paragraph 5 of the Criminal Code of the Republic of Latvia in the following wording: "Theft, when committed in significant amount, as well as theft of cars or other motor vehicles, narcotic, psychotropic, toxic or radioactive substances, explosives, weapons, ammunition, gas pistols (revolvers) or its cartridges - is punishable by deprivation of liberty for a period of six years and up to fifteen years with confiscation of property." In practice, as a the result of the implementation of the said amendments, the court based on the comprehensive, complete and impartial investigation of all circumstances of the case in its entirety, according to law and legal consciousness, had applied to car thieves fair and proportionate punishment.

On 17 June 1998, the Saeima of the Republic of Latvia adopted the Criminal Law currently being in force in Latvia. At the present moment, in Latvia, liability related to theft of a vehicle is prescribed according to Section 175 of the Criminal Law - Theft. The vehicle, as a threat object of the crime, is not separated from the concept of the general crime object of theft. In the Criminal Law, the lawmakers establish qualifying features for the qualification of theft, listed in Section 175, Paragraph 2 - for a person who commits theft, if it has been committed by a group of persons according to a prior agreement; Paragraph 3 - for a person who commits theft, if it has been committed by entering an apartment or other premises, or if it has been committed from a storage facility, from a system connecting storage facilities, or from a means of transport. Paragraph 4 - for a person who commits theft, if it has been committed in significant amount (currently $21500 \mathrm{EUR}$ ), as well as if it has been committed by an organized group, as well as if specified threat objects of crime are stolen: narcotic, psychotropic, powerfully acting, toxic or radioactive substances, explosives, firearms or ammunition.

As a result of the application of the provision of Section 175 of the Criminal Law, a situation developed 
in practice that for an offender who commits theft of a motor vehicle with the value up to 21500 EUR the applicable punishment in accordance with Section 175, Paragraph 1 - deprivation of liberty for a period of up to two years. According to statistics, the average age of vehicles stolen is -13 years with the market price of 900-8000 EUR per one motor vehicle. However, when stealing a vehicle, it must be entered at first - the door must be unlocked, ignition key must be switched on and engine must be started, these are the obstacles that will be overcome by an offender, and only after this the offender will able to handle the vehicle at his own discretion. According to the authors, the penetration into a vehicle and into an apartment do not differ from each other by the method of penetration, because the penetration both into a vehicle and into an apartment is mostly happened through doors and windows, the only difference is that the vehicle is a moving object. However, the disposition of Section 175 Paragraph 3 of the Criminal Law does not include penetration into a vehicle in the concept of penetration.

According to the author's point of view, the application of the norm of Section 175 of the Criminal Law enables in this situation to criminals, especially members of a group or an organized criminal group, to avoid an adequate and fair punishment.

The crimes where the motor vehicle is the object of threat are an activity of international organized criminal groups that has an impact on the whole world (Vehicle Crime, 2018). Interpol notes in its report that theft of a vehicle happens every ten seconds.

Analyzing the statistical data about theft of motor vehicles from 2014 until 2017 in the world, it is necessary to conclude that the dynamics of theft of motor vehicles makes heavy impression. In 2000, 2498543 motor vehicles were stolen, in 2014 - 6892 161, and in 2017 - already 7191940 motor vehicles (Database Statistics, 2018). In Europe, the increase in the number of offences whose threat subject is motor vehicle was largely influenced by changes in the political structure: the removal of the "iron curtain", acquisition of independence by the Baltic States, further enlargement of the European Union (EU), which meant the elimination of controls at the borders between the EU countries, as well as, new organized cybercrime groups arise, whose members have the most comprehensive knowledge in the field of information technology, as well as the opportunity appeared to use the most up-to-date innovative technologies, including for achievement of unlawful goals (Vilks 2011, p. 201). Internationalization and development of innovative technologies create accelerate regional develoment (Shevyakova et al. 2019; Zeibote et al. 2019), alas side effect is increased insecurity (Tvaronavičienè 2018a; 2018b).

The objects of illegal activities of international organized criminality groups are mainly located in the more prosperous Member States in Western and Northern Europe (Serious and Organized Crime Threat Assessment 2017, p. 47). A small proportion of stolen motor vehicles is sold within the boundaries of the EU, while the majority of it as the whole or as parts was transported by sea -18.4 proc. and through the border checkpoints 69 proc. were transported to Eastern Europe, Central Asia, North Africa and the Middle East (Analytical Report Motor Vehicle Crime in Global Perspective 24 p.).

When analyzing the above mentioned findings, the authors conclude that the prevention and detection of theft of vehicles, taking into account all aspects, including globalization and cross-border aspects, are crucial both from the standpoint of the property protection, and from the attitude of the protection of the state and public interests.

\section{Criminological and criminal justice characteristics of crimes related to cultural objects}

Criminal offences committed due to the greediness has been investigated and categorized according to their direct threat object, the method of implementation, the nature of the subject of the crime, as well as the number of subjects. One of such threat objects is cultural objects.

Over the past decade, we observe an increasing trend of the illegal trade of cultural objects from countries of 
the Middle East that are affected by armed conflicts. The "black market" of art works becomes as lucrative as drugs, weapons and counterfeit goods. The topicality of the prevention and combating of the illegal circulation of cultural objects in Latvia is confirmed by the statistics of the Information Center of the Ministry of the Interior (hereinafter - the IC of the MI) on stolen and lost cultural objects. For example, in the period from 2008 until the end of 2017, around 891 thefts of cultural objects have been committed in Latvia, more than 1856 cultural objects have been stolen or lost. Of the all range of the stolen cultural object, 65 proc. are items of religious significance or religious items (Prettiesiski atsavinātie kultūras priekšmeti/ Unlawfully Dispossessed Cultural Items, 2018).

When defining the concept of a religious item, the authors take into account the determined threat items when stolen from churches, according to Article 588 of the Criminal Code of 1903 (Criminal Code, 1903, Art. 588), as well as the concept of a cultural object defined in the IC of the MI, namely: the religious item is an item to which some of religions pay homage as the blessed, as well as the item which is consecrated and used in the service of the church. Most religious items are lost in churches, prayer houses. In 2010, 12 thefts from churches and prayer houses were registered in Latvia, 10 in 2011, 30 in 2012, 5 in 2014, 9 in 2016, 9 in 2016 and 11 in 2017. Accordingly, the number of stolen religious items distributes as follows: in $2011-109$ items, in $2012-$ 282, in 2014 - 136, in 2015 - 124, in 2016 - 212, and in 2017 - 194 (Prettiesiski atsavinātie kultūras priekšmeti/ Unlawfully Dispossessed Cultural Items, 2018).

On the territory of Latvia, theft of religious items was punishable after the adoption of Christianity among the Latvian tribes in the 13th Century - during Livonia time, then during dependence time in the Polish-Lithuanian Commonwealth according to the Lübeck Law and the Magdeburg Rights. Theft was also punished based on the Statutes of the Grand Duchy of Lithuania, as well as during so called Swedish Times. After 1721, according to the Sudebnik for a person committing theft from the Church (in Russian: tserkovnaya tat'ba) the applicable punishment was the death penalty (Samokvasov 1908, 4p.). After 1 May 1846, the Russian Regulations on Criminal and Correctional Punishments (the Criminal and Correctional Code) defined the crimes against faith, and the following concepts were given: robbery was committed in the church, open theft was committed in the church, and theft with a qualifying indication - from the church (Ulozhenie o nakazaniyakh ugolovnykh $\mathrm{i}$ ispravitel'nykh, 1846, Art. 2130, 2140, 2149, 2166).

The Criminal Code of 1903, Article 588 for a person who committed theft from churches; and Article 589, Paragraph 2, for a person who committed robbery in the church, provided the following liability - forced labour of up to eight years, or imprisonment into a correctional facility for a period of not less than three years (Criminal Code 1903, Art. 588).

The new Criminal Code of 1933 introduced the Chapter 17 "Offences against Religious Feeling of Believers and Peace of Deceased" (Articles 300-305). As a result, the norms of the Law protected the freedom of consciousness and feeling of believers of all legally existing denominations in Latvia. Regarding theft of religious items, the new Criminal Law clarified certain concepts and systematized qualifying features as well as increased the punishment. Section 547, Paragraph 4 provided: "Whoever has stolen (...) a religious venerable item belonging to the church of legally existing faith in Latvia; (...) shall be punished with a correctional facility for a period of up to four years" (Criminal Code, 1933, Sect. 547).

After occupation and annexation of Latvia into the USSR, the inhabitants of Latvia being the great part lawobedient in their mentality, taking into account historically established relations with the neighbouring country, Russia, conformed in the developed situation to the communists sent from Moscow as well as local supporters of the Soviet regime, where the basis of the state administration philosophy was the Marxist-Leninist Theory and Scientific Atheism.

On 26 November 1940, the Russian Criminal Code of 1926 entered into force in Latvia. The norms of this Russian Criminal Code did not protect neither religion itself nor religious venerable items belonging to the church, unless they were recognized as an antiquarian value, art collection or monument. The Chapter 17 
"Offences against Religious Feeling of Believers and Peace of Deceased" of the former Criminal Code was excluded as such from the Russian Criminal Code. On the contrary, the legislators, based on the theory of Marxism-Leninism and the theory of the warlike atheism, prescribed in the Chapter 4 liability regarding the violation of provisions of partition of the Church and the State by imposing restrictions on religious studies, collection of donations, registration of births and marriages. All this had a negative effect on the feeling of believers and the attitude towards the State.

The classification feature - theft from churches lost its special meaning in the Russian Criminal Code. As a result, such threat objects of criminal offence as religious items were included in the general concept of "property" (Ugolovnyy Kodeks RSFSR, 1926, Art. 162, 165, 167). In case of theft or robbery of religious items, a spiritual person of a religious organization or a godly person had to claim the amount of the loss. This was the first problem, because the value of a holy cross or a icon can be determined without doubt if the item is available, but if the item was stolen, then only according to the owner's oral information. From public officials, the loyalty against clergy and godly people, in this case, against victims, was very critical, if not to say that it was not trustworthy at all. It was so, because the theory of Marxism-Leninism denied the existence of God, therefore, the clergy are deceivers and there is no belief in them. The second problem was related to the fact that victims had to take into account and evaluate whether the stolen religious items were not antiquities or objects of art, whether they had to be registered or whether they had been hidden from state officials; because responsibility was prescribed for hiding the antiquities, art collections and monuments. At that time, repressions against several people happened in Latvia, including against clergymen and wealthy, godly people. Many were shot or taken to labour camps. People understood that atheistic legislation of Soviet power does not defend neither the spiritual values of believers, religious sensibilities of believers nor religious items. The struggle against believers ended with the invasion of the Nazi German army to the USSR during the Second World War and the occupation of the territory of Latvia in June-July 1941.

As the calamities of the Second World War were overcome and the country's economic situation improved, the Ministry of Culture of the USSR and local soviet executive committees began the process of registration and evaluation of the cultural heritage. This process had not only an economic but also a political ground. First of all, to execute the inventory of most valuable religious items with the aim to use them in favour of the state, and secondly, to replace the rich historical past with the history of the formation of socialism, to replace the traditional spiritual values of Latvian people with the communism dogmas. Unfortunately, many issues related to the assessment of religious items were solved by low-competence people. As a result, in the early 1960s, some churches were destroyed in Latvia, others were adapted to the planetarium, concert halls and boxing clubs; and dispossessed religious items "disappeared in the collections of the homeland".

In the Criminal Code of the Latvian SSR, legislators continued separation of the church from the state, providing in Article 137 of the Special Part, Chapter 4 "Crimes Against Citizens' Political, Labour and Other Rights" a punishment related to violation of the provisions regarding the separation of the church from the state and the separation of the school from the church. Religious items were not separated from the common concept of "property". Only the Chapter 10 "Crimes against Public Safety, Public Order and Health of the Citizens", Article 206 "Destruction or Damage of Monuments", prescribed responsibility for deliberate damage or destruction of historical, archaeological, art or architectural monuments, as well as objects of nature protected by the state (Ugolovnyy Kodeks Latviyskoy Sovetskoy Sotsialisticheskoy Respubliki, 1983, Art. 206). This meant that if churches or religious items were recognized as a monument of history, archaeology, art or architecture protected by the state, then responsibility for their deliberate damaging or destruction was prescribed.

On 22 August 1991, the CC of Latvia with amendments came into force; however religious items were also not separated from the common concept of "property".

On 25 May 1993, amendments of the CC of Latvia were made. These amendments expressed Articles 137 and 206 in another wording: Article 137 "Breach of the Equality of Citizens in Their Attitude towards Religion. In regard to the direct or indirect limitation of the rights of citizens, creation of any benefits to citizens depending 
on their attitude to religion, as well as infringement of the citizens' feeling or raising hatred because of their attitude to religion or atheism". The legislators excluded the norm - separation of the church from the state and separation of the school from the church, by creating a norm of a broader content - the restriction of the rights of citizens; Article 206 "Destruction of Monuments. On deliberate complete or partial destruction of cultural monuments, as well as objects of nature protected by the state", in comparison with the Criminal Code of the Latvian SSR the following norm was excluded - the monuments of history, archaeology, art or architecture and the following concept was introduced - the cultural monument (the Latvian Criminal Code, 1995, str.78, 130).

On 1 April 1999, the Criminal Law entered into force, where Section 151 "Disturbance of Religious Rituals" prescribed liability for the deliberate disturbance of religious rituals if they did not violate the law and were not related to violations of the rights of a person, however, on 13 December 2012 this Section was excluded at all. Section 229 "Destruction of and Damage to Cultural Monuments", Paragraph one provided for liability regarding the destruction of or damage to a cultural monument protected by the state and Paragraph two, if it has been committed by arson, blasting or in any other dangerous way. Currently, after the executed amendments, there is possible to apply the provisions of Section 229 more broadly and to call to justice not only for the destruction of or damage to a cultural monument protected by the state, as it was defined in the basic wording, but also for profanation, illegal coming-out outside the Republic of Latvia, as well as for unlawful expropriation and with qualifying feature, if it causes significant damage to the interests of the state or society.

Relating to the subject of the article, it is important to know whether the church has a status of a cultural monument and is included in the List of cultural monuments protected by the state, or not. If the status has been granted, then it will be a qualifying feature within the conception of Section 229 of the Criminal Law. As of 31 December 2016, 8924 objects were listed in the List of the cultural monuments protected by the state (Valsts kultūras piemineklu aizsardzības inspekcija/State Inspection on Protection of Culture Monuments, Annual Report, 2016). In practice, many administrators of the churches do not address with an application to assign the status of a cultural monument to a church not only because the church does not meet the status of a cultural monument of national or local significance in accordance with the criteria prescribed in the normative acts on cultural monuments, but also because they consider that for believers are not important, whether the church has such status or not, the key factor is the faith. Predominantly, it concerns Orthodox churches and Old Believer prayer houses. As a result, believers or religious organizations that own the church are greatest loser. From March 2012 until 9 October 2012, 23 thefts from the churches in Latgale region were registered, of which only 8 churches were of cultural monument status; and 122 icons, 13 sacred crosses and 6 holy books were stolen. As a result, this has arouse a wide resonance in the society, because the most believers considered and considers that the churches were repeatedly burgled, but no thief was ever caught and nothing of the stolen values had been returned. However, after several months of investigation and international cooperation, police officers managed to detain the perpetrators of the crime - citizens of Lithuania and Latvia, and return, unfortunately, only 10 icons, but one of them was found in Great Britain during the public auction.

Theft of religious items is a very specific kind of larceny. In order to commit theft of religious items from the churches, criminals must agree on the distribution of roles, taking into account the skills of each member of the group, because it is necessary: to enter the room by overcoming various obstacles (inset locks and padlocks, windows and/ or door grids and sometimes also alarms); to choose properly the most valuable religious item in a very short time and in a non-lightened space; to distribute the item on the "black market" or to a customer after theft without disclosing the fact that the religious item has been stolen. It should be also taken into account that the range of buyers of such religious items is narrow and closed.

Summarizing the above expressed, the authors conclude that the trends in decrease of amount of thefts and stolen religious items are not found. There is an urgent need to identify the peculiarities and difficulties of finding, seizing and investigation of religious items, as well as to evaluate the effectiveness of the solutions and tools used, in order to be able to apply a proportionate punishment to the guilty persons taking into account not only the material but also the spiritual value of the religious items. 


\section{Conclusions}

The globalization processes have an impact on both the country's social-economic processes, the policy of criminal punishments, the cross-border aspect, and lawmaking applicable in the country.

According to the European Security Strategy (ESS) - combating organized criminality is one of three priorities, together with terrorism and cybercrimes. Exactly, representatives of organized criminality are involved in theft of motor vehicles and religious items. The authors conclude, taking into account all aspects including crossborder aspects, that the prevention and detection of above mentioned crimes is crucial from both - from the standpoint of the protection of property and protection of interests of the state and society.

The trends in decrease of amount of thefts and stolen motor vehicles and religious items are not found. According to the authors' point of view, the successful investigation of above mentioned crimes is burdened with the gaps in the Criminal Law of Latvia.

Namely, first of all, the motor vehicle and religious item as threat objects of the crime have been not separated from the general concept of the offence object of theft, in opposite to that, how it is done with drugs or explosives and weapons.

Secondly, the disposition of Section 175, Paragraph 3 of the Criminal Law, entering a vehicle does not include into the concept of penetration. As a result, criminals, using these gaps in the Criminal Law, avoid the adequate and fair punishment. Regarding the legal framework, the authors propose to express Section 175, Paragraph 3 (175 (3)) of the Criminal Law in the following wording: "(3) for a person who commits theft or theft of a motor vehicle, if it has been committed by entering an apartment or other premises, or $\mathrm{f}$ it has been committed from a storage facility, from a system connecting storage facilities, or from a motor vehicle/ means of transport... ".

Thirdly, to have the opportunity to apply proportionate punishment to a guilty person, taking into account not only material but also spiritual value of the religious item, the authors offer to start a discussion among lawyers on necessity to supplement the objects of criminal offense in Section 175, Paragraph 4 (175 (4)) with the concept of a religious item, expressing Section 175, Paragraph 4, in the following wording: “ (4) for a person who commits theft, if it has been committed in significant amount, as well as if it has been committed by an organized group, as well as commits theft of narcotic, psychotropic, powerfully acting, toxic or radioactive substances, explosives, firearms, ammunition or religious item, ...".

\section{References}

Analytical repot Motor Vehicle Crime in Global Perspective, (2014). Available on Internet: https://www.interpol.int/en/contentinterpol/ search?SearchText=Motor+Vehicle + Crime + in + Global + Perspective $\& x=8 \& y=2-20140124 \% 20$ WEBSITE $\% 20$ public $\% 20$ version $\% 20$ (1).pdf

Brezhgo, B. Dinadurgas pilsetas privilegija 1582.gads- Daugavpils: Latgola, (2009). 87 [Brezhgo B. Dinaburg city privilege 1582]

Čentéš, J.; Mrva, M.; Krajčovič, M. 2018. The process of individualisation of punishment in insolvency crimes, Entrepreneurship and Sustainability Issues 6(2): 603-619. http://doi.org/10.9770/jesi.2018.6.2(10)

Chistyakov, O. I. Rossiyskoye zakonodatelstvo X-XX vekov [Chistyakov O. I., Russian legislation of the 10th-20th centuries]. Available on Internet: https://studfiles.net/preview/2164888/ page: 11/ ст. 28-38

Database statistics of Interpol, (2018). Available on Internet: https://www.interpol.int/en/Crime-areas/Vehicle-crime/Database-statistics

Dworzecki, J.; Nowicka, I. 2019. Organized crime in the production and distribution of falsified medicines in Poland: Outline of the problem, Entrepreneurship and Sustainability Issues 6(4): 1762-1770. http://doi.org/10.9770/jesi.2019.6.4(15)

Iekchlietu ministriyas Informaaciyas centrs Zuduchie kultuuras priekchmeti 2018.g Prettiesiski atsavinetie kultuuras priekchmeti [Information Center of the Ministry of the Interior Lost cultural objects in 2018 Cultural objects seized unjustly]. Available on Internet: http://www.ic.iem.gov.lv/lv/node/707 
Ivančiks, J.; Tumalavičius, V.; Teivāns-Treinovskis, J. (2015). Security of society: narcotics and drug addiction in Latvia and Lithuania, Journal of Security and Sustainability Issues 4(4): 353-368. https://doi.org/10.9770/jssi.2015.4.4(4)

Krastinsh, U. Kriminallikumam 10 gadi: tapshana, attistiba un perspektīva: - LU: Nr. 1. Yuridicheskaya nauka, 2010. [Krastiņš U. For Criminal Law 10 Years: Creation, Development and Perspective: - LU: Nr. 1. Legal science]. Available on Internet: https://www.lu.lv/ fileadmin/user_upload/lu_portal/apgads/PDF/LU_Juridiska-Zin_Nr-1.pdf 7.lpp. 6.lpp

Latvijas Kriminaal kodekss. Komentaari pie atsevichk'iem Kriminaalkodeksa pantiem. - R.: Latvijas Republikas Tieslietu ministrijas Tiesiskaas informaaciyas centrs, 1995, 78.lpp. [Latvian Criminal Code. Comments on individual articles of the Criminal Code. R .: Legal Information Center of the Ministry of Justice of the Republic of Latvia, 1995, p. 81]

Laužikas, M.; Miliūtè, A. 2019. Transformational communication via evolving ethical and moral norms of Lithuanian civil service organizations, Entrepreneurship and Sustainability 6(4): 1750-1761. http://doi.org/10.9770/jesi.2019.6.4(14)

Lavrinenko, O.; Ohotina, A.; Amosova, J.; Teivāns-Treinovskis, J. (2017). Intercompany networks of the cross-border region (LatviaLithuania-Belarus), Journal of Security and Sustainability Issues 7(1): 39-54. https://doi.org/10.9770/jssi.2017.7.1(4)

Mezulis, D. Iipachuma kriminaaltiesiskaa aizsardziiba -Riiga: Jumava, (1997). 36-41.pp. [Protection of property in criminal matters].

N̦esterova, M.; Teivāns-Treinovskis, J.; Ivančiks, J. (2015). Security and public safety: impact of gender on prisoners'justice perception, Journal of Security and Sustainability Issues 4(4): 403-413. http://dx.doi.org/10.9770/jssi.2015.4.4(7)

Omelchenko, O. F. (2000). Rimskoye pravo, Moscow., TON-Ostrozh'ye c. 77, [Roman Law].

Samokvasov, D.YA. Kurs istorii russkogo prava-Moscow. (1908). -VII, XXIX, 616 s [Samokvasov D. Ya. The course of the history of Russian law-Moscow: 1908. -VII, XXIX, 616 c.]. Available on Internet: https://books.google.lv/books?isbn=5446075331

Serious and organised crime threat assessment, (2017). Available on Internet: https://www.europol.europa.eu/activities-services/mainreports/european-union-serious-and-organised-crime-threat-assessment-2017

Shevyakova, A.; Munsh, E.; Arystan, M. 2019. Information support for the development of tourism for the diversification of the economy of Kazakhstan, Insights into Regional Development 1(2): 138-154. https://doi.org/10.9770/ird.2019.1.2(4)

Shtayman, I. (2005). Iz istorii gosudarstva i zakona Latvii - Riga: BRI 219. [From the history of the state and law of Latvia -Riga: BRI].

Sodu likums 1033 gada 24 aprilya [Penal Law 24 April 1933]. Available on Internet: https://dspace.lu.lv/dspace/handle/7/12831933 gada_24_aprila_sodu_likums_1934_sn113455.pdf

Statut velikogo knyazhestva Litovskogo 1529 goda, Razdel trinadtsatyy, O vorovstve st. 1 [The status of the Grand Duchy of Lithuania in 1529, Section Thirteen, On theft of art. one]. Available on Internet: http://vostlit.narod.ru/Texts/Dokumenty/Litva/XVI/1520-40/ Statut1529/text13.htm

Tekst Sudebnika 1497 goda st. 8-10. [Text of Code of Law in 1497]. Available on Internet: http://scicenter.online/istoriya-gosudarstvascicenter/tekst-sudebnika-1497-99970.html

Trofimovs, I.; Ivančiks, J. (2017). Psychological aspects of operational and investigative activities as a factor of strengthening of national security, Journal of Security and Sustainability Issues7(1): 55-65. https://doi.org/10.9770/jssi.2017.7.1(5)

Trofimovs, I.;Ivančiks, J. (2017). National security strengthening through the operational activities law, Journal of Security and Sustainability Issues 6(3): 391-400. http://dx.doi.org/10.9770/jssi.2017.6.3(6)

Tumalavičius, V.; Greičius, S. (2017). Decision Making of the Ensuring Public Security at the Level of the State Territorial Borders, Journal of Security and Sustainability Issues, 7(1): 27-37. http://dx.doi.org/10.9770/jssi.2017.7.1(3)

Tumalavičius, V.; Nikolayevskyy, V.; Endziņš, A. (2017). Issues of the State and Society Security (Part II): Management of Control over Individual Criminal Processes, Journal of Security and Sustainability Issues 6(4): 605-618. DOI: http://doi.org/10.9770/jssi.2017.6.4(6)

Tumalavičius, V.; Šakočius, A. (2017). Ensuring Public Security in the Field of Traffic Safety, Journal of Security and Sustainability Issues 7(2): 233-246. DOI: http://doi.org/10.9770/jssi.2017.7.2(5)

Tumalavičius, V.; Veikša, I; Načisčionis, J.; Zahars, V.; Draskovic, V. (2017). Issues of the State and Society Security (Part I): Ensuring Public Security in the Fight against Crime, Journal of Security and Sustainability Issues 6(3): 401-418. http://dx.doi.org/10.9770/ jssi.2017.6.3(7)

Tvaronavičienè, M. 2018a. Toward efficient policy making: forecasts of vulnerability to external global threats, Journal of Security and 
Sustainability Issues 7(3): 591-600. https://doi.org/10.9770/jssi.2018.7.3(18)

Tvaronavičienė M. 2018b. Towards internationally tuned approach towards critical infrastructure protection, Journal of Security and Sustainability Issues 8(2): 143-150. https://doi.org/10.9770/jssi.2018.8.2(2)

Ugolovnyy kodeks Latviyskoy Sovetskaoy Sotsialisticheskaoy Respubliki: M-vo yustitsii LatvSSR. - R.: Avots, 1983 608s. [Criminal Code of the Latvian Soviet Socialist Republic: M-in Justice of the Latvian SSR.].

Ugolovnyy Kodeks RSFSR redaktsii 1926 goda: Glava sed'maya Imushchestvennyye prestupleniya [Criminal Code of the RSFSR of the 1926 edition: Chapter Seven. Property crimes]. Available on Internet: https://ru.wikisource.org/wiki/Уголовный_кодекс РСФСР_1926_года/Редакция_05.03.1926

Ulozhenie o nakazaniyakh prestupnykh i ispravitel'nykh 1845 goda. [Ulozhenie about punishments criminal and correctional in 1845]. Available on Internet: https://vk.com/doc20559902_437521740?hash=4a7bdf15570fc55da2\&dl=69e1aa427fe5224329

Valsts kultuuras piemineklu aizsardziibas inspekciya 2016. Gada darba paarskats. [National Inspection for Heritage Protection 2016 Annual report]. Available on Internet: http://mantojums.lvmedia/uploads/dokumenti/publiskie_parskati/parskats_2016.pdf

Vehicle crime, (2018). Available on Internet: https://www.interpol.int/en/Crime-areas/Vehicle-crime/Vehicle-crime

Vilks, A. Jauno tehnolog'iyu izmantochanas tendences noziegumu noveerchanas un apkarochanas jomaa Zinaatniskie raksti: - Riga: RSU, (2011). 201. lpp. [Trends in the Use of New Technologies in the Prevention and Combating of Crime Scientific Papers].

Zahars, V.; Stivrinieks, M. (2016). Security and safety enforcment: execution peculiarities, Journal of Security and Sustainability Issues 6(1): 71-83. http://dx.doi.org/10.9770/jssi.2016.6.1(5)

Zeibote, Z.; Volkova, T.; Todorov, K. 2019. The impact of globalization on regional development and competitiveness: cases of selected regions, Insights into Regional Development 1(1): 33-47. https://doi.org/10.9770/ird.2019.1.1(3)

About contributors:

Jānis IVANČIKS (1946-2018), Ph.D, is a professor of the Law Department of the Social Science Faculty at Daugavpils University and the Law Department of the Law Faculty at the Turiba University. Research interests: Criminal Justice; Criminal Law; Criminal Intelligence; Security and Sustainability Issues.

Igors TROFIMOVS is a Doctoral candidate in the Law of Daugavpils University; Lecturer of the State Police College of Latvia and the Social Science Faculty at Daugavpils University. Research interests: Criminal Law; Criminal Intelligence; Issues of National, State and Regional Security.

ORCID ID: orcid.org/0000-0001-7539-9499.

Jānis TEIVĀNS-TREINOVSKIS, PhD, Professor is a Dean of Faculty of Social Sciences of Daugavpils University. Research interests: Criminal Law, Penal Law, Criminology, Security and Sustainability Issues.

ORCID ID: orcid.org/0000-0002-1440-2153.

This work is licensed under the Creative Commons Attribution International License (CC BY). http://creativecommons.org/licenses/by/4.0/ 